\title{
Lichens and lichenicolous fungi of the "Wrzosowisko Sowno" nature reserve (NW Poland)
}

\author{
ANETTA WIECZOREK, KATARZYNA HNAT \\ Department of Ecology and Environmental Protection, Institute of Biodiversity, University of Szczecin, ul. Wąska 13, 71-415 Szczecin, \\ Poland; e-mail: anetta.wieczorek@usz.edu.pl
}

Keywords lichens, nature reserve, Poland, Pomerania

\begin{abstract}
Lichens of the "Wrzosowisko Sowno" nature reserve in the western part of Polish Pomerania were studied in 2006 and 2014. Within the examined area, 90 species of lichens were observed. Eighteen species are included in the red list of threatened lichens in Poland, eight as vulnerable (VU) (Bacidia rubella, Bryoria fuscescens, Buellia disciformis, Calicium viride, Ochrolechia androgyna, Pertusaria pertusa, Pseudoschismatomma rufescens, Ramalina farinacea, $R$. pollinaria and Tuckermannopsis chlorophylla), seven as near threatened (NT) (Chaenotheca furfuracea, Evernia prunastri, Graphis scripta, Hypogymnia tubulosa, Pertusaria coccodes, Vulpicida pinastri and Zwackhia viridis), two as endangered (EN)( Melanelixia glabra and Pleurostica acetabulum) and one as critically (CR) (Melanohalea exasperata).
\end{abstract}

\section{Porosty rezerwatu "Wrzosowisko Sowno" (NW Polska)}

Słowa kluczowe porosty, rezerwat, Polska, Pomorze

Streszczenie Badania nad biotą porostów rezerwatu „Wrzosowisko Sowno” przeprowadzono w latach 2006-2014. Na badanym obszarze stwierdzono 85 gatunków porostów i 5 grzybów naporostowych. Ponad 52\% bioty porostów stanowiły gatunki nadrzewne, wśród których występowały taksony rzadkie i zagrożone w skali całego kraju. Blisko połowę gatunków stanowiły porosty o plesze skorupiastej. Najmniej licznie reprezentowane są epility, co zwiazane jest z brakiem odpowiednich siedlisk dla tej grupy porostów.

\section{Introduction}

The floristic reserve "Wrzosowisko Sowno" is located in West Pomerania Province, within Gryfice County, $2 \mathrm{~km} \mathrm{NW}$ of the town of Płoty. Although the reserve created in 1977 covers 39.3 ha, the peatland covers over 26 ha. It is a transitional mire composed of Sphagnum mats (typical of raised bogs) with Scheuchzeria palustris, but their upper layers in the course of time were partly dried and overgrown by birch woods. Salix thickets and patches of vegetation dominated by mosses and sedges (Janowska et al., 2003-2004) have developed at its edges. 
The habitat is an Atlantic wet heath specific to the nature of the Baltic coast in the western part of Polish Pomerania, with the characteristic Erica tetralix and Ledum palustre. They are accompanied by other Atlantic species, especially of Sphagnum mosses and boreal species of the family Ericaceae. This study aimed to investigate the species composition of lichens and lichenicolous fungi in the reserve.

\section{Material and methods}

The analysis of lichen flora is based on materials collected during field research conducted in the years 2006-2014. The random point method was used, which enabled us to explore the area objectively and evenly. Part of the reserve, especially the innermost portion, was not explored because of difficult access (waterlogged area, thickets).

Easily identifiable species of lichens were recorded in the field, while all the others were collected and identified in the laboratory of the Department of Ecology and Environmental Protection of the University of Szczecin. As a result of the research at 238 sites, 1909 records were collected (herbarium specimens or records in the field) (Figure 1).

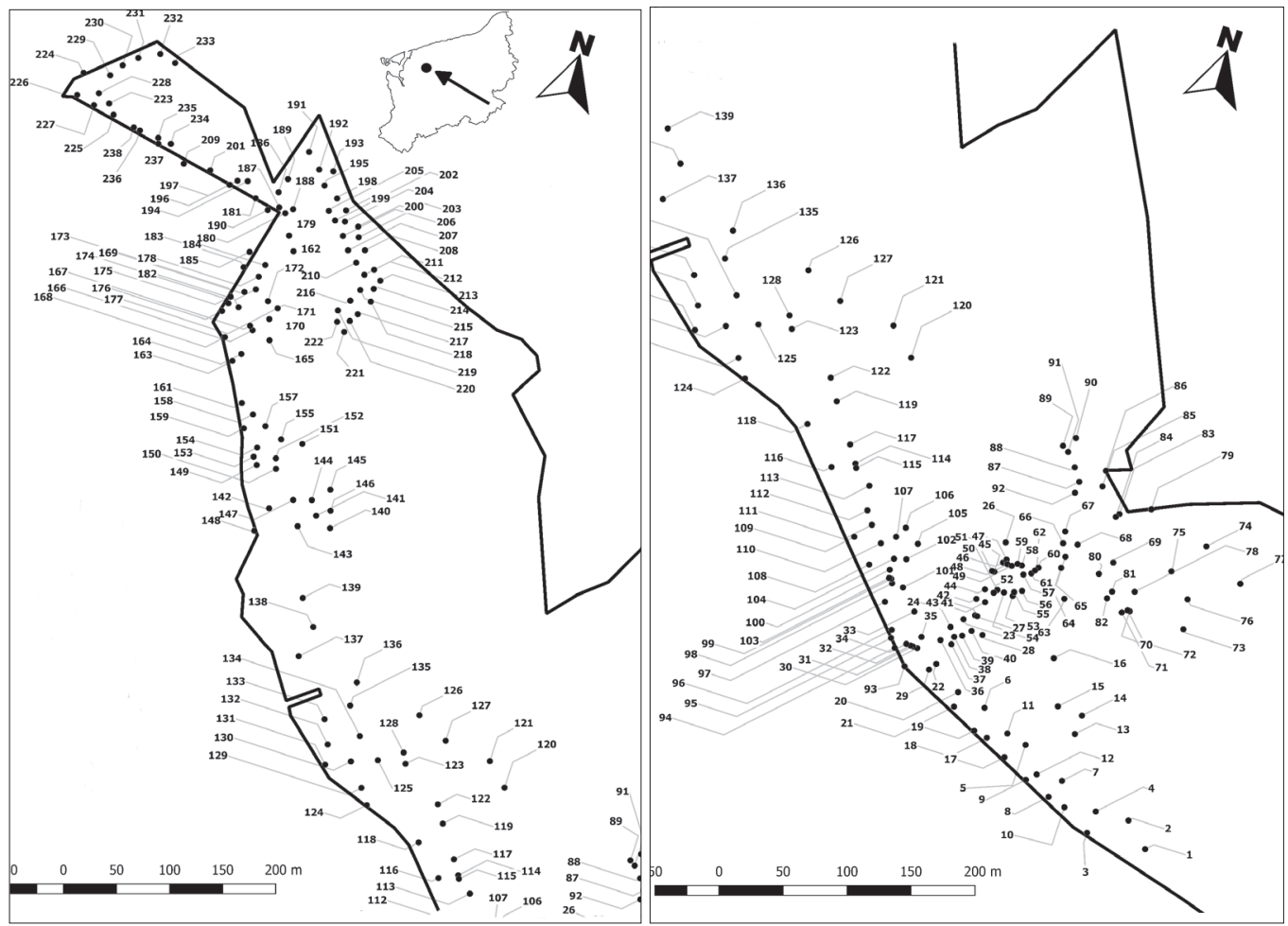

Figure 1. Study area and location of points 
Species names follow Fałtynowicz and Kossowska (2016), and Czyżewska and Kukwa (2009).

The list of threatened species, with their threat status, is based on the Polish red list (Cieśliński et al., 2006).

The list of species is ordered alphabetically. Types of substrate are given for each species. Names of lichenicolous fungi are marked with asterisks (*).

\section{Results}

In the "Wrzosowisko Sowno" nature reserve, 85 species of lichens and 5 lichenicolous fungi were found.

\section{Epiphytic lichens}

Epiphytic species are the dominant group, accounting for $52 \%$ of the total lichen biota of the study area (Figure 2). The largest number of species was found on bark of Betula sp. (36 species), which accounted for $20 \%$ of epiphytic lichens. Slightly smaller numbers were found on the bark of Quercus sp. (31 species, 18\%), Fagus sylvatica (26 species, 15\%), and Populus sp. (22 species, 12\%). They are accompanied by the lichen biota of Corylus sp. (14 species, 8\%), Pinus sylvestris (13 species, 7\%), Salix sp. (12 species, 7\%), Frangula alnus (9 species, 5\%), and Acer sp. (6 species, 3\%) (Figure 3). Most of the recorded epiphytic lichens are not exclusive but found on bark of various tree species (Figure 4). Exclusive species, found on bark of only one plant host, include: Arthonia radiata (on Fagus sylvatica), Bryoria fuscescens (Quercus sp.), Chaenotheca furfuracea (Quercus sp.), Cladonia cornuta (Betula sp.), Graphis scripta (Fagus sylvatica), Melanelixia fuliginosa (Betula sp.), M. glabra (Quercus sp.), Ochrochelia androgyna (Betula sp.), Zwackhia viridis (Fagus sylvatica), Pertusaria albescens (Fagus sylvatica), P. coccodes (Quercus sp.), Platismatia glauca (Populus sp.), Ramalina pollinaria (Betula sp.), and Vulpicidia pinastri (Betula sp.).

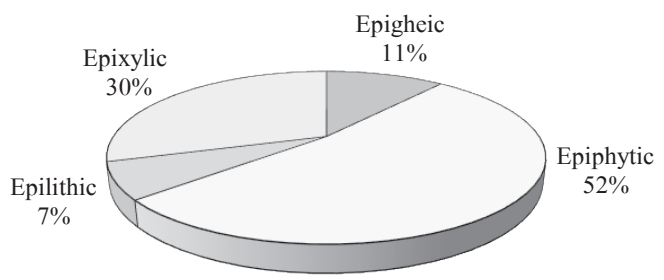

Figure 2. Percentages of lichen species from various ecological groups 


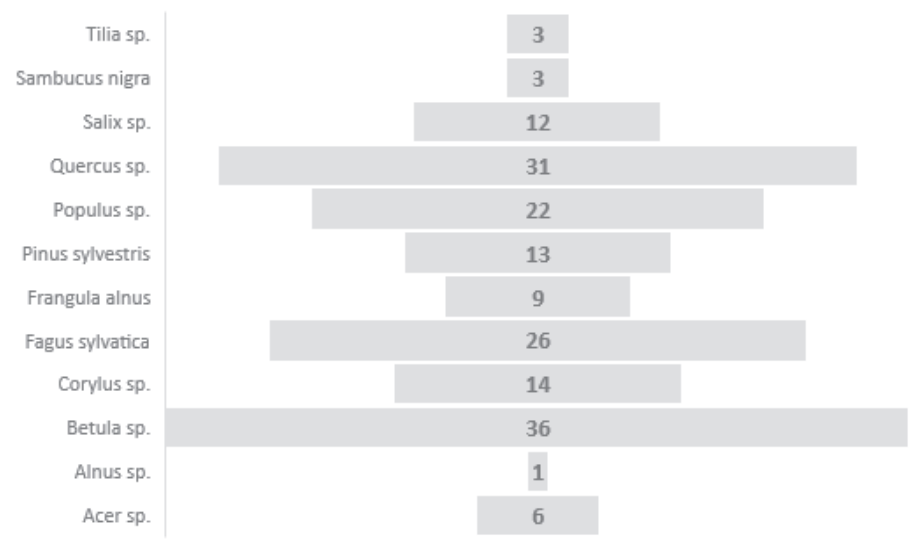

Figure 3. Contribution of epiphytic lichens on examined trees

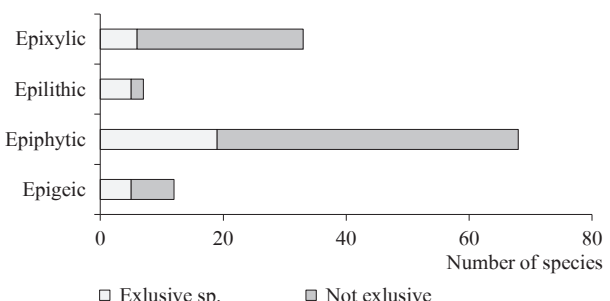

Figure 4. Contribution of exclusive and non-exclusive species in ecological groups of lichens

Most of epiphytic lichens have crustose thalli, accounting for over $50 \%$ of the total number of species of epiphytic lichens (Figure 5).

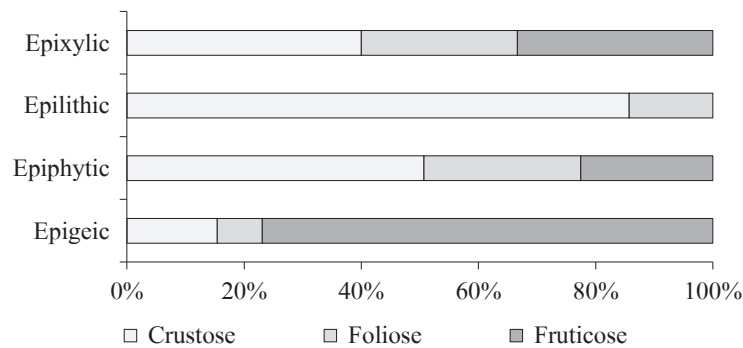

Figure 5. Spatial distribution of lichen species and contributions of morphological forms to each ecological group 
The group of epiphytes is dominated by taxa that are frequent or common in the western part of Polish Pomerania (Fałtynowicz, 1992). Only few are protected by Polish law and/or threatened in Poland (Cieśliński et al., 2006). These include Bacidia rubella (VU = vulnerable), Bryoria fuscescens (partly protected, VU), Buellia disciformis (VU), Chaenotheca furfuracea $(\mathrm{NT}=$ near threatened), Evernia prunastri (NT), Graphis scripta (NT), Hypogymnia tubulosa (partly protected, NT), Melanohalea exasperata (CR = critically endangered), Melanelixia glabra (EN = endangered), Ochrolechia androgyna (VU), Pseudoschismatomma rufescens (VU), Pertusaria coccodes (NT), P. pertusa (VU), Pleurosticta acetabulum (partly protected, EN), Ramalina farinacea (partly protected, VU), R. pollinaria (partly protected, VU), Zwackhia viridis (VU), and Vulpicida pinastri (partly protected, NT).

\section{Epixylic lichens}

On decaying or rotting wood, 35 lichen species were found, accounting for $30 \%$ of the lichen flora of the study area (Figure 2). They were mostly frequent and common lichens of the genera Cladonia, Micarea, Placynthiella, and Trapeliopsis. A vast majority of epixylic species were not exclusive to one host species (82\%) (Figure 4). In moist patches near the mire, young stumps were usually colonized by crustose lichens, accounting for $40 \%$ of the total number of epixylic species (Figure 3). These include Lecanora conizaeoides, Micarea denigrata, Placynthiella uliginosa, and Trapeliopsis flexuosa. On stumps with more strongly decomposed wood, they were succeeded by fruticose lichens, mostly of the genus Cladonia, frequently also Hypocenomyce scalaris and Lepraria sp.

\section{Epigeic lichens}

In the "Wrzosowisko Sowno" nature reserve, epigeic lichens accounted for nearly $11 \%$ of the total number of species (Figure 2). Most of them were not exclusive but grew at the bases of many tree species (Figure 4). Fruticose lichens prevailed among them (Figure 5). Epigeic lichens were found at the edges of the mire and of forest glades. They were represented most often by lichens of the genus Cladonia. Species associated with thermophilous sandy pine forests, such as Cladonia arbuscula subsp. mitis, Cladonia uncialis, were less frequent. Only sporadically we recorded Bacidia bagliettoana, Peltigera rufescens, Cladonia rangiferina (partly protected).

\section{Epilithic lichens}

This group of lichens was represented exclusively by species found on anthropogenic substrates, such as concrete poles or walls, and accounted for only $7 \%$ of the lichen flora of the study area (Figure 2). The group consists of only 8 species, with crustose thalli, including common calcicolous lichens: Flavoplaca citrina, Calogaya decipiens, Candelariella aurella, Myriolecis albescens, M. dispersa, and Lepraria sp.

\section{Discussion}

The species composition of lichens of "Wrzosowisko Sowno" nature reserve is conditioned primarily by specific environmental conditions associated with the presence of the mire. Many species were found at sites that are not accessible to average tourists, so it can be assumed that they are not subject to strong human pressure. The presented results of the research on the biota of 
the peatland reserve are consistent with data from other small nature reserves in northern Poland (Fałtynowicz, 1996). The dominant species are epiphytic, common or frequent in the western part of Polish Pomerania. Also the lack of epilithic species is characteristic in the nature reserves, which is associated with the absence of suitable substrates.

Nearly $30 \%$ of the recorded epiphytic taxa were rare and threatened, reported from 1-2 localities in reserve Their presence in the reserve attests to the high species diversity of the lichen biota of the reserve and it is an important refuge for rare and threatened species.

\section{List of species}

For each species, the type of substrate on which it is found and numbers sites are given. Symbols: $*=$ lichenicolous fungus $\mathrm{CR}=$ critically endangered, $\mathrm{EN}=$ endangered, $\mathrm{VU}=$ vulnerable, $\mathrm{NT}=$ near threatened; $\mathrm{PR}=$ strict or partial protection.

Acarospora fuscata (Nyl.) Arnold - on concrete posts: 86, 93, 148, 187.

Amandinea punctata (Hoffm.) Coppins \& Scheid. - on birch, and poplar tree bark, and wood: 6, 8, 11, 20, 22, 41, 51, 54, 63, 72, 99, 100, 111, 127, 129, 131-134, 144, 145, 176, 181, 207, 226. Arthonia radiata (Pers.) Ach. - on beech tree bark: 25, 30, 67.

Athalia holocarpa (Hoffm.) Arup, Frödén \& Søchting - on concrete posts: 3, 79, 148.

*Athelia arachnoidea (Berk.) Jülich - on thallus of Lecanora conizaeoides on pine tree bark: 11, 23, 25, 45, 80, 71, 82, 92, 98, 118, 119, 129, 132, 181, 184, 185, 193, 226, 230, 232, 237.

Bacidia rubella (Hoffm.) A. Massal. - [VU], on wood: 28.

Bryoria fuscescens (Gyeln.) Brodo \& D. Hawksw. - [PR, VU], on oak, beech tree bark: 8, 27, 50,101, 130, 180, 187, 190, 195, 207.

Buellia disciformis (Fr.) Mudd - [VU], on oak tree bark, and wood: 45, 74, 75, 84, 153, 162, 198.

B. griseovirens (Turner \& Borrer ex Sm.) Almb. - on oak, birch, maple, poplar, and beech tree bark: 4, 15, 16, 27, 56, 59, 80, 88, 106, 120, 136, 140, 145, 221.

Calogaya decipiens (Hoffm.) Arup, Frödén \& Søchting - on concrete posts: 3, 93, 148, 190.

Candelariella xanthostigma (Ach.) Lettau - on birch, poplar, and linden tree bark: 6, 90, 111, 156. Chaenotheca chrysocephala (Ach.) Th. Fr. - on wood: 214.

C. ferruginea (Turner ex Sm.) Mig. - on birch, pine, oak, and poplar tree bark, and wood: 2, 10, $12,27,32,58,61,62,64,66,71,73,79,81,84,88,91,154,191,209$.

C. furfuracea (L.) Tibell - [NT], on oak tree bark: 88 .

Chrysothrix candelaris (L.) J.R. Laundon - on oak tree bark: 78 .

Cladonia cenotea (Ach.) Schaer. - on wood: 36.

C. chlorophaea (Flörke ex Sommerf.) Spreng. - on birch, poplar, oak tree bark, and wood: 7, 8, $10-12,15,19,23,30-32,48,51,58,63,64,68,71-73,78,80,92,94,98,99,102,108,111$, $114,116,122,126,127,132,135,138,139,145,156,157,160,171,177,179,185,188,191$, 196, 202, 208, 212, 219.

C. cervicornis (Ach.) Flot. subsp. verticillata (Hoffm.) Ahti - on soil: 36.

C. coniocraea auct. - on poplar, birch, linden, beech, and hazel tree bark, and wood: 1, 2, 6, 10-22, 25-29, 32, 34, 37, 39, 42, 58, 63, 64, 69, 72, 81,108, 109, 114, 119, 133, 152, 173, 219, 225, 233.

C. cornuta (L.) Hoffm. - on birch tree bark: 71,

C. deformis (L.) Hoffm. - on wood, soil, and rare birch tree bark: 13, 18, 24, 30, 34, 39, 41, 43, 48, $53,57,58,60,64,66,68,71,72,74,78,83,88,98,103,105,111,116,126,127,132,140,146$, 157, 160, 162, 167, 173, 184, 185, 191, 196, 198, 200, 202. 
C. digitata (L.) Hoffm. - on birch, oak, and pine tree bark, and wood: 7, 12, 15, 16, 26, 30, 32, 34, $48,52,58,60,62,64,69,71,79,88,89,91,95,102,104,118,121,123,126,128,135,139$, 141, 146, 171, 173, 177, 184, 188, 192, 208, 221.

C. fimbriata (L.) Fr. - on birch, oak, and poplar tree bark, and wood: 3, 10, 13, 15, 16, 18-21, 23, $24,28,33,41,51,55,57,59,60,62-64,68-71,73,74,78,79,83-85,87,89,90,92-94,96$, $99,100,102,106,108,109,113,119,123,125,126,130,133,135-141,145,146,152,154$, 160-162, 165, 171, 223, 232, 233.

C. floerkeana (Fr.) Flörke - on wood, and soil: 7, 49, 56, 86, 110, 132, 173, 220.

C. furcata (Huds.) Schrad. - on soil: 13-16, 70, 71-73, 75-78, 105, 106, 114, 115, 117, 119-121, $126,127,136,162,165,170,172,200,202,203,205-208,210,211,215-217$.

C. glauca s.l. Flörke - on birch, and oak tree bark, soil, and wood: 4, 6, 12, 14, 22, 23, 27, 38, 39, $73,76,80-82,86,87,92,99,108,110,119,120,127,136,139,140,143,145,151,162,165$, 179, 198, 202, 206, 208, 211, 215, 220.

C. macilenta Hoffm. - on soil, wood, and birch, poplar tree bark: 3, 5, 6, 11-16, 20, 22-24, 27, 28 , $32-35,44,49,54-56,58-60,63-65,71-74,76-78,80,83-85,90,91,98-100,104-107,114$, $115,119,122,123,126-128,139-141,144,146,150-152,155-157,164,165,170-173,179$, 188-193, 195, 198, 200-205, 211-215, 218-221, 230-233, 235, 236.

C. rangiferina (L.) Weber - on soil: 13, 16, 73 .

C. subulata (L.) Weber - on soil, wood, and birch tree bark: 5, 8, 12, 15, 16, 19, 23, 26, 32, 34, 36, 43, 47-49, 55, 58, 61, 62, 64, 79, 81, 88, 95, 108, 115, 121, 126, 146, 157, 185, 219.

C. uncialis (L.) F.H. Wigg. - on soil: 15, 221.

*Clypeococcum hypocenomycis D. Hawksw. - on thallus of Hypocenomyce scalaris on pine tree bark: 5, 13, 32, 36, 81, 100, 102, 111, 126, 192.

Coenogonium pineti (Schrad.) Lücking \& Lumbsch - on oak, and beech tree bark, and wood: 1 , $2,11,12,15,17,19,21,23,24,30,39,43,47,63,78,95,112-114,121-123,125,135,173,192$, 196, 199, 223, 224, 232, 235.

Evernia prunastri (L.) Ach. - [NT], on willow, poplar, and oak tree bark, and rare wood: 3, 11, $19,27,33,36,41,43,44,47,49,68,72,80,94,95,109,127,152,174,186,187,190,192,195$, 210, 219, 220, 222, 235, 236, 237.

Flavoplaca citrina (Hoffm.) Arup, Frödén \& Søchting - on concrete posts: 3, 79, 93, 148, 190.

Graphis scripta (L.) Ach. - [NT], on beech tree bark: 51, 53.

Hypocenomyce scalaris (Ach.) Choisy - on pine, and oak tree bark, and wood: 5, 12, 13, 15, 16, 23, 26, 32, 36, 38, 71, 81, 100, 102, 108, 111, 113, 119, 126, 128, 192, 236.

Hypogymnia physodes (L.) Nyl. - on pine, oak, willow, poplar, beech, and maple tree bark, and wood: 1-17, 19, 22-25, 27, 29, 30, 33, 34, 36, 37, 39, 40, 41, 42, 44-47, 49-52, 54-59, 61, 63, $65,68-70,72-74,77,78,80-85,87,88-100,102,106-110,114-119,121,125-127,129,130$, 133, 135-139, 141-143, 146, 154, 158, 160-163, 165, 168, 169, 171, 173-177, 186, 187, 195, 196, 200-202, 212, 220, 222, 224, 226-232, 234-236.

H. tubulosa (Schaer.) Hav. - [PR, NT], on birch, oak, willow, and pine tree bark, and wood: 14, 16, 27, 72, 111, 123, 126.

*Illosporiopsis christiansenii (B. L. Brady \& D. Hawksw.) D. Hawksw. - on thallus of Physciatenella on birch tree bark: 8, 34, 74, 129.

Lecanora carpinea (L.) Vain. - on poplar beech, and hazel tree bark, and wood: 24, 25, 43, 60, 66, 191.

L. chlarotera Nyl. - on wood: 26 . 
L. conizaeoides Nyl. - on birch, poplar, beech, hazel, and oak tree bark, and wood: 1, 11, 16, 19, $20,22,23,25,45,46,56,57,63,80,71,72,74,75,78,82,84,85,92,98,103,107,109,118$, $119,128,129,132,150,163,181,184,185,193,195,197,200,208,221,226,227,228,230$, 232, 233, 237, 238.

L. expallens Ach. - on birch, poplar beech, and oak tree bark: 7, 21, 34, 55-58, 89, 99, 112, 140, 157, 185, 187,190-196, 210-214.

L. pulicaris (Pers.) Ach. - on pine, birch, poplar, beech, and oak tree bark, and wood: 8, 23, 25, 33, 38, 56, 70, 78, 99, 101, 104, 110, 143, 156-159, 170, 182, 196, 203, 206.

L. saligna (Schrad.) Zahlbr. - on oak, beech tree bark: 36, 57, 77, 101.

Lecidella elaeochroma (Ach.) Choisy - on willow, and pine tree bark: 15, 34, 67, 88, 121, 193.

Lepraria sp. (L.) Ach. - on poplar, oak, maple, hazel tree bark, and wood: 1-3, 5-13, 15-28, 30-85, 87-99, 101-104, 106-133, 135-177, 179-181, 183, 184, 186-196, 198-208, 210-215, 219-227, 229-236, 238.

*Lichenoconium erodens M. S. Christ. \& D. Hawksw. - on thallus of Hypocenomyce scalaris, Hypogymnia physodes and Lecanora conizaeoides: 25, 30, 33, 34, 72, 84, 197, 238.

*Lichenoconium lecanorae (Jaap) D. Hawksw. - on apothecia of Lecanora conizaeoides: 11, 16, 25, 45, 80, 71, 72, 84, 118, 197, 238.

Melanohalea exasperata (De Not.) O. Blanco, A. Crespo, Divakar, Essl., D. Hawksw. \& Lumbsch - [CR], on birch, and hazel tree bark, and wood: 28, 73, 93.

M. exasperatula (Nyl.) O. Blanco, A. Crespo, Divakar, Essl., D. Hawksw. \& Lumbsch - on birch tree bark: 7, 96, 174.

Melanelixia fuliginosa (Fr. ex Duby) O. Blanco, A. Crespo, Divakar, Essl., D. Hawksw. \& Lumbsch - on birch tree bark: 84 .

M. glabra (Schaer.) O. Blanco, A. Crespo, Divakar, Essl., D. Hawksw. \& Lumbsch - [EN], on oak tree bark: 19.

Micarea denigrata (Fr.) Hedl. - on wood: 7, 9, 123.

Myriolecis albescens (Hoffm.) Śliwa, Zhao Xin \& Lumbsch - on concrete posts: 79, 93, 148.

M. dispersa (Pers.) Śliwa, Zhao Xin \& Lumbsch_- on concrete posts: 3, 79, 93, 148, 190.

Ochrolechia androgyna (Hoffm.) Arnold - [VU], on birch tree bark: 62, 78.

Parmelia sulcata Taylor - on birch, pine, poplar, willow, oak, beech, hazel, and linden tree bark, and wood: 1-6, 8-12, 17, 19, 20, 22-24, 27-29, 31, 36, 39, 41, 43, 44, 47, 49, 50-53, 55-57, 59, 61, 64, 65, 67-73, 75-77, 79, 80, 82, 83, 86-91, 94-96, 101, 103, 105, 106, 108, 109, $111-113,115,116,118,121,122,124,125,127,129,132-135,137,139,143-145,151,152$, $154,155,157-163,166,168,169,173,174,179,186,187,190,196,200,210,221,222,227$, 232, 235-238.

P. saxatilis (L.) Ach. - on birch and alder tree bark: 6, 37, 94, 165.

Parmeliopsis ambigua (Wulfen) Nyl. - on birch, beech, willow, and poplar tree bark: 2, 3, 6, 11, 13, 19, 73, 85, 154.

Peltigera rufescens (Weiss) Humb. - on soil: 72, 76, 126, 140.

Pertusaria albescens (Huds.) Choisy \& Werner - on beech tree bark: 76, 163.

P. amara (Ach.) Nyl. - on hazel, and beech tree bark: 9, 55, 135.

P. coccodes (Ach.) Nyl. - [NT], on oak tree bark: 24, 77, 162.

P. pertusa (Weigel) Tuck. - [VU], on hazel, and beech tree bark: 9, 72, 87, 104, 125, 148, 181, 222.

Phaeophyscia nigricans (Flörke) Moberg - on linden, and birch tree bark, and on concrete posts: 93, 148, 190, 197, 234.

P. orbicularis (Neck.) Moberg - on poplar tree bark: 235 . 
Phlyctis argena (Ach.) Flot. - on beech, hazel, and oak tree bark: 7, 26, 31, 67, 85, 91, 94-96, 165, 174, 175, 237.

Physcia adscendens (Fr.) H. Olivier - on hazel, and willow tree bark: 1, 196, 231.

P. tenella (Scop.) DC. - on birch, tree poplar, hazel, willow bark, and wood: 1, 3, 4, 6-10, 12, 17-24, 26-30, 32, 34, 36, 37, 40, 41, 43-45, 49-53, 55, 57-61, 65, 67, 68, 70-80, 82, 83, 85-89, 91-101, 103-116, 119-122, 125-130, 132, 134-139, 141-170, 176, 178-180, 184, 189, 190, 196, 199, 200, 201, 202, 206, 208, 212, 217-219, 223, 226, 232, 233.

Placynthiella icmalea (Ach.) Coppins \& P. James - on hazel tree bark, and wood: 8, 48, 53, 57, 68, 71, 86, 92, 94, 96, 112, 1124, 184, 162, 164, 185, 233.

P. uliginosa (Schrad.) Coppins \& P. James - on soil: 8, 75, 86, 94, 108, 111, 132, 143, 185, 192, 196, 198, 200.

Platismatia glauca (L.) W.L. Culb. \& C.F. Culb. - on poplar tree bark: 17, 103, 107.

Pleurostica acetabulum (Neck.) Elix \& Lumbsch - [PR, EN], on oak, birch maple tree bark: 11, 24, 36, 40, 50, 55, 62, 72, 78, 85, 96, 106, 117, 132, 149, 170, 210.

Polycauliona candelaria (L.) Frödén, Arup \& Søchting - on oak, willow, and beech tree bark: $3,9,44$.

P. polycarpa (Hoffm.) Frödén, Arup \& Søchting - on willow, birch, maple, poplar, and oak tree bark and wood: $3-6,9,10,17,19,24,29,31,34,37,41,48,51,52,54,57,59,60,61,63,65$, $68,74,76,77,83,84,92,94,96,97,100,101,105-107,112,113,116,124,127,144,146,157$, 169, 195, 215, 216, 231.

Porina aenea (Wallr.) Zahlb. - on beech tree bark: 8, 44, 51, 53, 55.

Pseudevernia furfuracea (L.) Zopf - on oak, beech, and birch tree bark: 11, 85, 90, 135.

Pseudoschismatomma rufescens (Pers.) Ertz \& Tehler - [VU], on beech, and hazel tree bark: 8, 87. Ramalina farinacea (L.) Ach. - [PR, VU], on oak, maple, willow tree bark: 6, 16, 24, 51, 65, 112, 184.

R. pollinaria (Westr.) Ach. - [PR, VU], on birch tree bark: 64, 52.

Scoliciosporum chlorococcum (Graeve ex Stenh.) Vězda - on pine, hazel tree bark: 22, 43, 50, 61, 68, 88, 111, 135.

Trapeliopsis flexuosa (Fr.) Coppins \& P. James - on wood, and birch tree bark: 7, 10, 15, 18, 24, $30,32,33,36,43,49,56,60,68,75,86,92,99,111,116,124,132,154,162,185,191,198$, 200, 209, 219, 233.

T. granulosa (Hoffm.) Lumbsch - on soil, wood, and birch tree bark: 9, 12, 16, 19, 24, 29, 30, 33, 51, 62, 63, 72, 78, 88, 108, 109, 113, 119, 132, 135, 146, 184.

Tuckermannopsis chlorophylla (Willd.) Hale - on oak, and beech tree bark: 7, 48, 54, 79, 124, 167, 213.

Usnea dasopoga (Ach.) Nyl. - on birch tree bark: 51, 94, 109, 132, 184, 223.

Violella fucata (Stirt.) T. Sprib. - on beech tree bark: 67.

Vulpicida pinastri (Scop.) J.-E. Mattsson \& M.J. Lai - [PR, NT], on birch tree bark: 3, 64, 160.

Xanthoria parietina (L.) Th. Fr - on willow, birch, oak, poplar, pine, and beech tree bark, and wood: 3-6, 8, 10, 17-28, 30-36, 39-41, 43-48, 50-53, 57, 63, 64, 66, 68, 70, 72-78, 80, 82-86, 89, 92, 94, 97-100, 102, 103, 105, 108, 109, 111, 112, 114-116, 127, 129, 131, 132, 134, $137,143,144,146,149,150,157,158,160,164,167,173-175,177,179,182-193,195-200$, 203, 207, 208, 210, 212, 217, 218, 221-224, 226-229, 232-236, 238.

Zwackhia viridis (Ach.) Poetsch \& Schied. - [PR, NT], on beech tree bark: 8 . 


\section{References}

Cieśliński, S., Czyżewska, K., Fabiszewski, J. (2006). Red list of the lichens in Poland. In: Z. Mirek, K. Zarzycki, W. Wojewoda, Z. Szeląg (eds.), Red list of plants and fungi in Poland (pp. 72-89). Kraków: W. Szafer Institute of Botany, Polish Academy of Sciences.

Czyżewska, K., Kukwa, M. (2009). Lichenicolous Fungi of Poland. A Catalogue and Key to Species. In: Z. Mirek (ed.), Biodiversity of Poland (pp. 1-133). Kraków: W. Szafer Institute of Botany, Polish Academy of Sciences.

Fałtynowicz, W. (1992). The lichens of Western Pomerania (NW Poland) an ecogeographical study. Polish Bot. Stud., 4.

Fałtynowicz, W. (1996). Porosty rezerwatu "Bagnisko Niedźwiady" i "Bagno Biel”, zasługujących na ochronę torfowisk na Pomorzu Zachodnim. Parki Nar. Rez. Przyr., 2 (15), 3-11.

Fałtynowicz, W., Kossowska, M. (2016). The lichens of Poland. A fourth checklist. ActaBot. Siles., Monogr., 8, 3-122.

Janowska, J., Kowalski, W.W.A., Zyska, P. and W. (2003-2004). Plan ochrony rezerwatu Wrzosowisko Sowno. Wykonany na zlecenie Wojewódźkiego Konserwatora Przyrody w Szczecinie.

Cite as: Wieczorek, A., Hnat, K. (2017). Lichens and lichenicolous fungi of the "Wrzosowisko Sowno" nature reserve (NW Poland). Acta Biologica, 24, 149-158. DOI: 10.18276/ab.2017.24-13. 